\title{
The 'cognitive' and the 'emotive' component in Christian songs: Tracing the shifts in traditional and contemporary songs
}

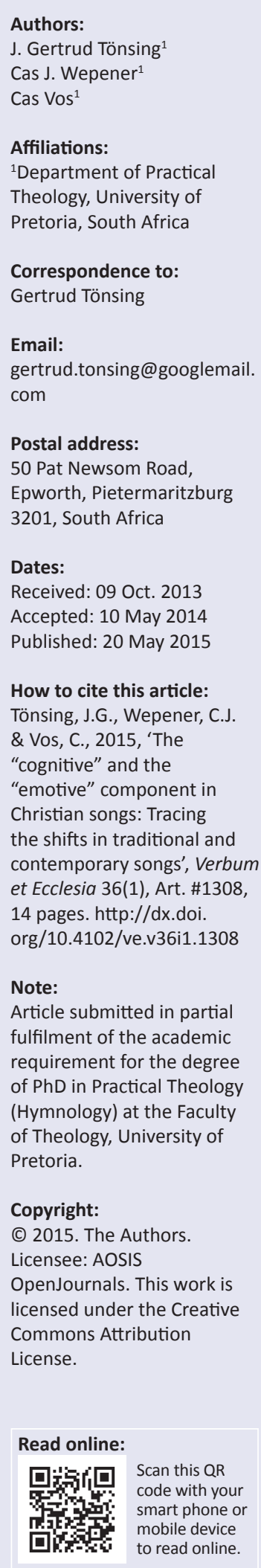

This research article is based on the author's doctoral research into the question of quality criteria for Christian songs. In many Christian congregations today, the question of music is an emotive issue as the service and its music touch the heart of people's faith life and shapes people's theology. Of the many issues that were investigated in the dissertation, this article focuses on one question only, the question of the 'cognitive' and the 'emotive' value of the songs that are sung in a Sunday service. It will be argued that, in 'good' songs, there needs to be a good balance between 'cognitive' and 'emotive' value. The general question is how to identify songs that can nurture faith and sustain people through life. Characteristic of such songs is, amongst many other criteria, a good balance between the cognitive and emotive value of the text and the tune. In the discussion, the author focusses largely on her own Lutheran liturgical and hymnological tradition as well as on the 'Praise and Worship' movement which has a dramatic impact on churches all over the world. The author argues that finding songs that balance the emotive and the cognitive component is an effective way to bridge the divides on worship music within a congregation.

Intradisciplinary and/or interdisciplinary implications: Within the discipline of hymnological studies, the article opens a ground-breaking new way to analyse and critique music used in worship with objective tools for analysis. This is, as far as the author knows, new for this discipline, and it also has an effect on other disciplines.

\section{Introduction}

This article is based on the author's doctoral research into the question of quality criteria for Christian songs. In many Christian congregations today, the question of music is an emotive issue as the service and its music touch the heart of people's faith life. Many people are attracted to services, or put off going, by the kind of music that is played and sung, and their walk of faith is interwoven with songs that have shaped and sustained their faith. Many people have had the experience that '... we get our theology far more often from the hymns we sing than from the sermons we hear' (Long 2001:54). Music and the choice of songs generate passion and conflict because they are so essential to faith.

Of the many issues that were investigated in the dissertation, this article focuses on one question only: What is the 'cognitive' and the 'emotive' value of the songs that are sung in a Sunday service. It is argued that, in 'good' songs, there needs to be a good balance between 'cognitive' and 'emotive' value.

In the article, 'song' is used in a generic sense to include church hymns, choruses, repetitive chants, gospel songs, contemporary worship songs and anything else that is sung in a worship setting or a gathering of Christians. I deliberately decided to use the rather undefined term 'good': 'What is a "good song"?' I try to demonstrate that this question is answered in very many different ways by pastors, worship leaders and congregants, and this divergence of opinions often leads to conflict. In this article, 'good' is defined in a particular way, and the research problem is narrowed down to the following: What are the characteristics of 'good' Christian songs that outlast their generation and are sung for decades or even centuries? Is it possible to predict which songs are likely to be sung for a while if one invests the effort to teach them to a congregation?

Some songs require little teaching and last a long time. Some are easily learnt and soon forgotten. Some require a little effort to teach and do not 'put down roots' in a congregation. The last category is made up of those songs that require a little effort to teach but then sustain a 
congregation for years. The central question of the research is how to identify songs belonging to this last category and whether one can give worship leaders some guidance as to how to choose such songs: quality songs to nurture faith and sustain people through life. Songs need to be 'owned' by a congregation. They become part of 'their' songs, of their identity. They become part of daily life, sung not only on a Sunday morning. ${ }^{1}$ Are there common features amongst the songs that a congregation is willing to 'own'? Luther calls such songs 'church hymns' which are used and accepted by people as if they had written them themselves. ${ }^{2}$ Characteristic of such songs is, amongst many other criteria, a good balance between the cognitive and emotive value of the text and the tune.

Most of the research for this article focussed on the literature, searching songbooks and listening to many CDs. There were also many informal discussions with people, but these were not formalised in structured interviews. These discussions have informed the questions rather than the answers of the research. Answers came mainly from extensive comparisons of successful or long-lasting songs in hymnals and song collections.

The discussion focusses largely on my Lutheran liturgical and hymnological tradition. It does also include the 'Praise and Worship' movement ${ }^{\prime 3}$ which has a dramatic impact on churches all over the world, also on the researcher's church. In referencing songs from printed hymnals, this article follows the convention within Hymnology of referring to these works by an abbreviation rather than by editor or publisher. A list of these abbreviations is found in the bibliography. Inclusive language will be used throughout to refer to human beings. However, for simplicity's sake, traditional male language has been retained in most places where referring to God. This use is simply practical and does not imply that God is exclusively male.

\section{Theoretical background}

This study is written within the discipline of practical theology, in particular in the area of hymnology, which is a sub-discipline of liturgical studies. Practical theology today is no longer seen as many separate sub-disciplines dealing mainly with the actions of the pastor but as a unified discipline with its own theoretical base. This common base was found to be communication (Heitink 1993:8). All sub-

\footnotetext{
1.In a book by Reinhard Deichgräber on the hymns of Jochen Klepper, the forme comments on the need for Christian songs to become part of daily life, to be comments on the need for Christian songs to become part of daily life, to be
sung anytime and anywhere during one's daily routine: 'auf Spaziergängen, beim sung anytime and anywhere during one's daily routine: 'auf Spaziergängen, beim immer neue Gelegenheiten zum Singen auf. Dabei merkt man bald, was an oder in einem Lied ist' (Deichgräber 2002:12).

2.Luther comments that even hymns by Ambrose are only church hymns because they were accepted by the people as their own: 'Es liegt daran, dass der Haufe Gottes oder Gottes Volk ein Wort oder Lied annehme oder für unrecht erkenne. St. Ambrosius hat viel schöner Hymnen gemacht, heißen Kirchengesang darum, dass sie die Kirche angenommen hat und braucht, als hätten sie dieselben gemacht und wären ihre Lieder' (Luther [1543] 2007:34).

3.I repeatedly refer to The Praise and Worship movement in this article, but it is not easy to define the movement. According to Robert Webber, this movement is characterised by a 'concern for the immediacy of the Spirit, a desire for intimacy, characterised by a concern for the immediacy of the Spirit, a desire for intimacy, and a persuasion that music and informat
Christian culture' (Webber 1994:128).
}

disciplines have to do with communicating the gospel to others and include not only the actions of the pastor but the action of the Church as a whole, in the lives of individuals, congregations and society as a whole (Müller 1974:24-25). Practical theology has its own theoretical base and theological rationale (Greinacher 1974:111-112) and can critique other disciplines from its empirical research (Van der Ven 1993:20).

There is no doubt that Christian singing is an example of such communicative action, falling within these definitions of practical theology. Besides the Bible itself, songs are one of the primary ways in which the Christian tradition has been codified to be mediated to the next generation, and it is a very important way in which each new generation mediates its own experience of faith. Asking what should be sung in a service falls under the critical task of practical theology and can be seen as a special instance of the theoretical question of the relationship between theory and praxis.

Practical theology has debated this question at length: Does theory come before praxis, or do the demands of praxis shape theory. What is the relationship between these? ${ }^{4}$ In traditional theology, this question was settled in favour of theory determining praxis. This would mean that the theologians and experts need to decide what the congregation sings as they are able to critically evaluate hymns and songs as to their theological and artistic merits and recommend only the songs of high value. Others, however, argue that praxis should determine theory, that is, congregations should try out what musical praxis actually works in bringing people to the worship service. Then one can reflect on this praxis and see what the new style of worship means for congregational reality. What is clear is that the praxis-driven approach is also driven by an underlying theoretical framework which is often unconscious, for example, in this case, the assumption that quantitative church growth is more important than qualitative theological or artistic considerations. The consensus now is that theory and praxis are indissolubly linked. Their relationship is one of 'bipolar tension', neither totally separate nor identical (Greinacher 1974:113), and it can be illustrated by an ellipse (Heyns \& Pieterse 1990:31). This article entails a reflection on praxis and should lead to a more conscious and changed praxis, which needs to be reflected on again.

As the research on songs was part of this reflection on communication processes, there was also a need for some reflection on hermeneutical processes. I can only touch on these briefly. Very important in the theoretical base for the thesis is the concept of communication as 'dialogue', which can happen with texts and songs just as it can with living persons (Osmer 2008:23). The philosopher Hans-Georg Gadamer used the metaphor of shifting

\section{See extensive discussion in Heyns and Pieterse (1990:23-32).}

5.Morgenthaler (1995) and Redman (2002) have written literature that positively and critically reflects on the Praise and Worship movement. This literature will probably influence and shape the praxis of this movement. This praxis was shaped initially by experience and the input of talented individuals rather than by theological reflection. 
'horizons' for the process of dialogue. In the process of genuine dialogue, one participant or both participants shift their standpoint to come closer to the horizon of the other (Taylor 2002:290). One learns to step into a 'foreign horizon' (Gadamer 1975:287) ${ }^{6}$ and tries to come to a place where one can at least partially see the horizon that the other sees. This leads to a process of 'fusion of horizons' (Horizontverschmelzung), which leads to the possibility of understanding (Gadamer 1975:289).

The fusion of horizons is a dynamic and critical metaphor for dialogue, and it is a useful image not only for understanding texts but also for musical appreciation. Exposure to different styles and information on the history of shifts in musical style can 'widen one's horizon' to appreciate the value of a style with which one is unfamiliar. The exclusive positions, 'hymns only' or 'contemporary praise and worship songs only', are examples of dialogue participants who are unwilling to shift their positions and explore the richness of other horizons. For a 'fusion of horizons' to occur, it is often important to try to keep different, seemingly opposite, poles in balance by means of a process of seeing them together in this dynamic process of understanding.

This article focuses on one issue and how the poles involved affect the dialogue between people concerned about singing in worship. This entails the conflict between people who at the one pole argue that we should sing only songs with good texts, songs that have a proclaiming character, and those who argue that we should be singing what people enjoy, songs that touch them emotionally because then they will come to the services and hear the word preached. Is there a way in which such dialogue can become fruitful and positive for worship? What kinds of song will bring these different perspectives together?

\section{The need for balance in worship}

Christian songs are sung in many settings, but their primary setting is the Christian worship service, usually on a Sunday morning, when Christians of a particular denomination gather together to sing, pray, praise and adore, listen to the word of God and, more or less often, celebrate Holy Communion together. It is primarily this congregational setting that determines what can or should be sung and what songs will survive. However, there are as many differences of opinion about what the Sundaymorning service is and should do as there are different theological approaches amongst Christians. This article cannot go into the debates around worship styles and what the aim of worship is. I will stay with the definition of the Lutheran World Federation's (1996) Nairobi Statement on Worship and Culture:

Worship is the heart and pulse of the Christian Church. In worship we celebrate together God's gracious gifts of creation and salvation, and are strengthened to live in response to God's

6.Im Prozess des Verstehens kann man versuchen selber in diesen Horizont hinein sich $\mathrm{zu}$ versetzen. Man verläßt den eigenen Standpunkt, und kommt zu dem anderen und versucht seinen Horizont zu verstehen (Gadamer 1975:287). grace. Worship always involves actions, not merely words. To consider worship is to consider music, art, and architecture, as well as liturgy and preaching. (n.p.)

However, here it will be argued that, within worship, different aims and elements need to be kept in balance.

There are many things which need to happen in worship, and sometimes, these aims are in tension. David Bosch (1991:381) speaks of a 'creative tension'. There is a need for speaking to the contemporary culture but also a need of preserving the best of past insights. There is a need to attract people without losing depth, a need to minister to people in their situation and a need to challenge them to change it. Marva Dawn (1995:58ff.) argues for the need to keep dialectical poles in balance and lists the following such polarities: 'tradition and Reformation', 'truth and love' and 'thought and feeling'. Luther wrote regularly on the tension between 'freedom' and 'love', which should inform any worship reform ${ }^{7}$ and which informed his decision to reverse some of the changes that his colleagues had made to worship forms while he was at Wartburg (Friedenthal 1982:395-396). Making connections between polarities is one way of promoting the kind of dialogue about which Gadamer speaks and of fostering a process of 'shifting' and 'fusing horizons' (Gadamer $1975: 287,289)$. As most people naturally tend to focus more on one of the polarities than on the other, consciously trying to maintain a balance keeps horizons from becoming rigid and unmoving and promotes an openness for dialogue and interaction.

The following list of 10 polarities arose in the reflection on the different polarities mentioned above and from interactions with traditional and contemporary liturgies and songs. These were the polarities which seemed most relevant to ensure a broadness of themes and a balance in worship and singing. Some others mentioned above are also relevant but will not be discussed in detail here:

- past versus present

- objectivity versus subjectivity

- cognitive versus emotive

- community versus individual

- familiarity versus diversity

- affirmation versus challenge

- cross versus glory

- transcendence versus immanence

- vertical versus horizontal

- universal versus particular.

In the dissertation, all these are discussed at length, as are the ways in which they play out in each of the songs that are analysed. This article focuses on the third of these polarities: cognitive versus emotive.

7.In his introduction to volume 53 of Luther's Works, Leupold (1965:xvi) writes: 'In this spirit of liberty and with this concern for the man in the pew, Luther planned this spirit of liberty and with this concern for the man in the pew, Luther planned the reformation of the cultus', and '... he shrank from innovations and avoided liturgical sensationalism because he had a pastor's concern for the faith and piety of the common people ... Neither Old nor New were ultimate values to him. He approached the tangled problem of tradition vs innovation with the freedom of the Christian man' (Leupold 1965:xiv-xv). 
This polarity deals with the 'head' versus the 'heart' in worship. Whilst both are needed, different traditions and denominations stress one more than the other. In the course of church history, the pendulum has swung from excessive sentimentality to dry objectivity and back again several times (see historical overview in following sections). Traditional services have been accused of being too 'head centred' just as many contemporary services have been critiqued for being too emotional. For many people, 'successful worship' means having 'felt' the presence of God, and they criticise the fact that they do not have these experiences in mainline services. ${ }^{8}$ These are realities that need to be taken seriously as, for most people, experiences and feelings are entry points to be able to hear the message. However, in some contemporary services, there seems to be pressure to produce feelings. Marva Dawn (1995:28) writes: 'Lacking sincere intimacy in congregational fellowship, we often put false pressure on worship to produce feelings of intimacy.'

Redman (2002) writes on Praise and Worship services:

A weakness among Pentecostals and charismatics is the frequently blurred line between experiencing God in worship and emotional release in worship ... emotionally expressive worship has a strangely addictive quality for many. This may lead some to worship their worship experience, rather than worship God ... The emphasis on the emotions in postmodern popular psychology may attract many postmoderns to charismatic worship who seek a new kind of emotional release. But the attraction quickly fades without a deep foundation in classic Christian theology and a rich worship experience that embraces the whole person and lifts the worshiper out of a solitary experience into a truly corporate setting. (p. 150)

In worship and, more particularly, in songs, a measure of emotion is needed as this is what touches people and makes them open to hear the word. Songs are a primary way to respond to what has been heard, and so some measure of emotion is appropriate. However, songs also need to proclaim and teach as they affect the theology that will be transmitted. The cognitive and the emotive element, though sometimes in tension, are not opposites. The best worship songs appeal to the whole person: the will, the emotions and the intellect. Music has a powerful role in stirring human emotion. This is precisely why it was viewed suspiciously by some reformers and has been carefully controlled by institutional churches (Van de Laar 2000:259). Yet as such, it is a powerful vehicle to convey cognitive content if these two poles are kept in balance.

The cognitive value of a song comes from the lyrics. The emotive value comes mainly from the tune, but the text can also contain emotive words and exclamations. Words can evoke a militant or erotic atmosphere. ${ }^{9}$ Typical emotive

8.Michael Nüchtern (2008:16-22) describes the situation in Germany where many people at the fringes of the church associate religion with the feelings that come from emotionally laden music at special times of life. There are often conflict around this with theologians and classically trained musicians who see these musical elements or songs as 'kitsch': too sentimental and theologically unacceptable.

9.Such as in the song by Paul Oakley and Martin Cooper Romance me: 'Romance me till my heart belongs to you ...' (SF III:1347). words, which may, however, be integrated into more contentbased lyrics are for example 'sweet', 'hold me close', 'soar', 'Jesus, lover of my soul' and 'I love you'.

Whether a song is too 'dry and cerebral' or 'too emotive' is an issue concerning which there will be differences of opinion. Someone will be deeply touched by a song which someone else experiences as manipulative. Others will be moved by theologically deep lyrics which yet others find too abstract and distant. If the goal is evangelism, then emotive appeal is very crucial to the choice of music. ${ }^{10}$ If the main goal is to form the character of committed congregation members, then there will be recognition that faith is formed not only by our feelings but also by our understanding of faith content, and there will be more emphasis on cognitive content in songs. Even committed congregation members, however, need some emotive appeal in songs for commitment to continue and to deepen.

\section{Tracing the balance in biblical texts and church-historical developments Old Testament singing}

Human beings have been using music in ceremonies and worship since long before recorded history, and they have known the power of music to stir emotions. This power has been either encouraged or manipulated or discouraged as dangerous by religious leaders throughout the ages.

In Old Testament times, the worshiping community definitely sang. The psalter with its 150 poems, which were all probably chanted rather than recited, has a central place in the Hebrew Scriptures. These songs have cognitive as well as emotive content. Many of them describe important events. Some of these are probably part of the oldest material in the Bible, for example the song of Miriam (Ex 15:21; Jeremias 2004:90) and the song of Deborah (Jdg 5:2ff.; Eissfeldt 1974:106; Jeremias 2004:89). At least since the time of David, if not before that, singing had a fixed place in the Israelite liturgical tradition. Music was acknowledged to have great power, to soothe the mind (1 Sm 10:5), to create an atmosphere favourable to ministry (2 Ki 3:14-16) and to help people to sense the glory of God (Letsosa \& De Klerk 2007:67). This shows that there was a positive openness to emotion in singing. This was positive emotion of thanks and praise but also negative emotion of anger and lament, such as the psalms written in exile. In Babylon, people sang in spite of the question 'How can we sing the Lord's song in a strange land' (Ps 137:4). In this time, Israel passionately wrestled with the meaning of faith in its God and came up with deep and profoundly influential answers ${ }^{11}$ (Zenger 1997:387). Psalms included

10.Reinke (2011:20) critiques the exclusion of emotion from church hymns and says it is often the feelings which open up people to the encounter with God. Different music works very differently on people.

11.'Die in der Exilszeit und in der früh-nachexilischen Zeit so immens anwachsende literarische Tätigkeit zeugen von der Leidenschaft, in der Israel damals die Gottesfrage neu stellt - und zu Antworten durchstieß, deren Tiefe und Ernst auch uns Heutige still und demütig machen' (Zenger 1997:387). 
personal and communal prayers, ${ }^{12}$ and this reflects liturgical and musical praxis (Zenger 1997:70). Israelite religion had a prohibition on visual images. It makes up for this by means of the strong visual images in its poetry (Zenger 1997:10-12). The breadth of topics in the Psalter and its inclusion of all human emotions and aspects of life is a great example to Christian singing.

\section{New Testament singing}

In New Testament times, Christians also sang. Extra-biblical evidence from the letter of procurator Pliny to the Emperor Trajan said about the Christians that they '... sing hymns to Christ as to a God (Carmen Christo quasi deo dicere)' (Albrecht 1995:13). Singing seems to have been a natural way to express themselves and their newfound faith in Christ. This was, firstly, a continuation of the Jewish tradition, but they also began to compose their own songs to Christ, some of which are probably included in the gospels and letters. Examples of these are the four songs in the infancy narratives of Luke: (Magnificat in Lk 1:46-55, Benedictus in Lk 1:68-79, the Gloria in Excelsis in Lk 2:14 and the Nunc Dimittis in Lk 2:29-32) and also the Pauline Christ hymn (Phlp 2:6-11). ${ }^{13}$ The content of these early hymns are mostly praise for Christ's salvation and proclamation of Christ as Lord, King and sacrificial lamb. Singing is an expression of joy (Ja 5:13), but it also has a teaching purpose (Phlp 2:5-11). In 1 Corinthians 14:15-39, Paul emphasises that what we sing in public worship should be understandable to the congregation and to the outsider. It should not simply edify the individual or even praise God but build up the congregation and draw it together. This would mean a rejection of pure emotion but not all emotion in singing. Cognitive teaching content is obviously important to Paul. The two most well-known passages about singing see the purpose as praising and thanking God but also as building the community (address one another Eph 5:19) and as proclamation and teaching (Col 3:16). The Greek grammar leaves unanswered the question whether the singing is a response to the teaching or whether the teaching happens in the singing. Here different translations come to different conclusions. ${ }^{14}$ This ambiguity may be deliberate so that the singing becomes both proclamation and response (Albrecht 1995:13). However, it seems clear that the singing is not addressed exclusively to God but also to fellow believers and to those outside who still need to hear the proclamation. These passages clearly support some proclamation happening through the songs.

12.Vos points out that the distinction between the individual and the collective, that is the ' $I$ ' as individual, or as Israel, is a modern distinction. The individual is conscious of being part of a people, and the community is conscious of being made up of individual and vulnerable people (Vos 2004:252).

13.Paul seems to quote and refer to the hymnic tradition regularly and, according to Jeremias (2004:89), saw this as foundational for his theology.

14.Translation variations: Interlinear... in all wisdom teaching and exhorting yourselves in psalms and hymns and spiritual songs' (Green 1985:915). Here the teaching happens in the songs. English Standard Version: '... teaching and admonishing one another in all wisdom, singing psalms and hymns and spiritual songs, with thankfulness in your hearts to God.' Here the singing is a separate songs, with thankfulness in your hearts to God.'
action from the teaching, linked with thankfulness.

\section{The Early Church and Middle Ages}

After early openness to diversity in singing, the authorities of the early church began to exercise control over what was sung in the service. Spontaneous songs, particularly those with high emotive value, were a powerful and dangerous vehicle for false doctrine. This can be seen in the Arian controversy. The Arian teaching was spread through songs, and the first great hymn writer, Ambrose Bishop of Milan (340-397), wrote orthodox songs against this, always ending with a doxology or praise to the Trinity (Routley 1983:9). ${ }^{15}$ After this, worship became increasingly restricted to a fixed liturgy with prescribed words and actions (Routley 1983:10). Whilst the words were restricted, the music was not. Early Gregorian chant was very simple and fairly unemotive, but in later medieval masses, the choir singing attracted more and more elaborate settings, often polyphonic, which made the words increasingly difficult to understand. The mass became an emotive drama, centred on the elevation of the sacred host (Driscoll in Wainwright \& Tucker 2006:208), but largely unintelligible to people. However, apart from public worship, the authorities could not restrict what believers sang, and a rich medieval tradition of carols and religious ballads and dances developed independent from formal public worship. This tradition became the focus for protest singing prior to the Reformation (Mitchell in Wainwright \& Tucker 2006:314).

\section{The Reformation}

The reformers uniformly critiqued the musical praxis of the medieval church, which excluded congregants and obscured the words of proclamation. However, they differed sharply as to what they proposed as its alternative. Their teaching affected the music and singing in those churches for generations.

Musically, Huldrych Zwingli is said to have been the most gifted of the three reformers. Perhaps because of this, he understood the power of music and its ability to influence emotions and faith. He felt and argued increasingly strongly that music is a worldly thing, which is good for relaxation and entertainment but dangerous because it manipulates feeling and distracts from spiritual endeavours. He argued for music and singing to be completely excluded from the service (Thompson 1961:142) so that people may give their ear to the word of God alone. From 1524 until 1598, there was no singing in the churches in Zürich and other areas influenced by Zwingli. Then they began to allow unaccompanied psalm singing as promoted by Calvin (Söhngen 1967:44).

John Calvin was not a musician and what he said about music was based on his theological reflections. For Calvin, the Word was supreme. Music to him was a useful carrier of the word but no more than that. It has no spiritual value in its own right. Like Zwingli, he thought that music was a human invention, easily misused to distract and manipulate

15.Some of the translations of Ambrosian hymns are still found in contemporary hymnals, for example Luther's translation of his hymn Veni Redemptor Gentium (Saviour of the Nations, come, ELW 263/EG 4). 
(Calvin [1536] 1960:32). He was wary of the ability of music to influence emotions and transport words deep into the hearts of people: 'When melody goes with it, every bad word penetrates much more deeply into the heart' (Preface to the Psalter in Opera selecta 2:17 in Leith 1981:211). For this reason, singing should be restricted to words from the Bible, mainly the psalms. Singing should be in unison and unaccompanied so that nothing would stand in the way of a clear understanding of the words to be proclaimed (Leith 1981:177). It was metrical psalm singing and the monumental work of the Genevan psalter which became characteristic of Calvinist worship and his most enduring legacy in worship reform (Leith 1981:185). Calvin's ability to draw in top quality poetic and musical talent brought the breadth of the human emotion of the psalter into Calvinist psalm singing. The Genevan psalter helped spread Calvinism throughout the world.

Martin Luther was a great lover of music and had a markedly different approach to music in worship than the other two reformers. He too was critical of the misuses in the medieval musical praxis but maintained that music is in its essence good, even if people misuse it (Luther [1524] 1965:316). He defended the use of music and the arts against fairly vociferous opposition (Luther 1854:297). He saw music as a gift of God and as very close to theology in its essence (Luther 1854:309). He opened the gates wide for all kinds of ways to use music in the service. Music can praise God on its own terms. It is not simply a carrier of the word. Luther encouraged people to write songs - words and tunes - and did not prescribe any style. His own hymns reached even a wider audience than his theological writings, leading his opponents to remark that Luther's songs 'destroyed more souls than his speeches and writings' (Blume 1965:27). He quite deliberately used music to teach but also saw music as a primary way of expressing Christian joy in faith (Luther [1545] 1965):

For God has cheered our hearts and minds through his dear Son, whom he gave for us to redeem us from sin, death, and the devil. He who believes this earnestly cannot be quiet about it. But he must gladly and willingly sing and speak about it so that others also may come and hear it. (p. 333)

Above all, for Luther, Christians sing to proclaim and share their faith. Through his emphasis on congregational singing, he placed the service firmly back in the hands of the congregation. The fact that Luther lifted restrictions on what and how to sing in services unleashed amazing creativity and made Lutheran areas leaders in church music for generations.

\section{Hymnology after Luther}

In the centuries after the Reformation, the balance between the cognitive and the emotive focus in songs swung repeatedly from end to end. This discussion is focussed mainly on Lutheran and Reformed Germany and England. In Lutheran services, congregational singing remained a fixture. People mostly sang from memory, and usually, there were authorised collections which determined what could be sung in the services. The denominational conflicts and concern about heresy again restricted what could be sung in a Sunday service (Albrecht 1995:107).${ }^{16}$ Outside, in the homes and Christian fellowships, in youth groups and revival meetings, newer songs had their place. A small percentage of these then found its way into the authorised hymnals, normally after some decades. ${ }^{17}$

The period after the Reformation was dominated by the denominational conflicts, and hymns were seen as a vehicle to teach the 'pure faith'. Emotion or the response of the believer was seen as less important. The official hymns were restricted to those of the prominent Reformers. A Lutheran psalter was commissioned to counter the influence of the Calvinist psalter in Germany. In Reformed Germany and England, the Psalter completely dominated congregational singing.

With the devastation of the Thirty Years' War in Germany (early 17th century), hymns became focussed more on the individual. Most of these hymns were intended for home use and were included in official hymnals only much later. There was more emotive content in the words and the tune and a growing emphasis on the individual faith response. Some baroque texts started to have the tendency to sentimentality ${ }^{18}$ (EG 956.3[1]). This led to the growth of the pietistic movement in the 17th century where songs focussed often exclusively on the personal faith relationship with Jesus and the emotional response to salvation. Tunes became increasingly complex and expressed spiritual fervour. In England, Isaac Watts asked why Christians should not sing about Christ and broke the monopoly of metrical psalmody.

The early 18th century was a time of revival and musical richness, producing composers such as Telemann, Bach and Handel and the hymn writers Tersteegen and Zinzendorf, the founder of the Moravian movement (EG 956.4 [1]; Routley 1983:36). In England too, the Methodist revival and the hymns of Charles and John Wesley brought hymnody to a new height. Charles Wesley's hymns brought together biblical teaching, proclamation and faith response. The resistance to 'freely composed' hymns continued in the institutional church, and the new hymns were largely sung outside of public worship (Routley 1983:39-41). This new height in hymnody was eroded when the enlightenment and biblical rationalism began to subject everything to human reason. Many hymns were discarded or rewritten, and few subjects besides creation inspired hymn writing. Hymns were dry and less emotive, often simply teaching

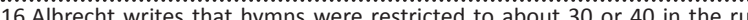
where most

17.The song collections of Johann Crüger, which will be discussed in the chapter on Paul Gerhardt, were not authorised hymnals for the church service. They were mainly used for groups and home devotions (Albrecht 1995:109). It took 50 years for the songs of Paul Gerhardt to be included in the authorised hymnals.

18.An example of this is Ermuntre dich, mein schwacher Geist, a hymn for Christmas by Johann Rist. In the older German Lutheran hymnal of 1974 (EKG 24), this hymn has 6 verses. Some of those with more emotive language have been cut in the next hymnal edition, (EG 33), which now has three verses. It might have been cut completely but for verse 4 which has been popularised in the Bach Christmas cut completely but for verse 4 which has been popular
Oratorio. Verse 4 has now become verse 1 in the EG. 
good morals. Many hymnologists call it the time of 'decay' (Blume 1965:217). Other groups countered the rationalism around them with a simple biblical faith or with Biblicism. Few hymns have survived from this era. ${ }^{19}$ In England, the Archbishop of York officially allowed hymns to be sung in worship (Routley 1983:50). This opened new possibilities in English hymn singing.

It was almost inevitable that the pendulum would swing back to emotion after the period of dry rationalism. The 19th century was a time of spiritual fervour, and hymnody gained new momentum. Old hymns were rediscovered and new ones written, which expressed a fervent, personal faith. Tunes were emotive, often dramatic, with a tendency to being sentimental. These songs became very popular and inspired the missionary movement, which carried them into other contexts. However, the sometimes excessive emotionalism of the romantic movement gave rise to a more critical liturgical movement at the turn of the century, which emphasised good taste and high standards in text and music. Hymn books were compiled and heavily emotional songs rejected. Hymns focussed on the proclamation of the faith. After the Second World War, jazz and popular styles began to influence Christian music, and there was less emphasis on quality or proclamation than on building community. It was again seen as important to attract others and to use music for effective evangelism. In the last decades of the 20th century, the Praise and Worship movement became prominent, which rediscovered the centrality of worship to Christian life and aimed at enabling people to have an intimate and emotional encounter with God in the "Holy of Holies' (Webber 1994:130-131). Worship leaders rose to prominence in this emotionally engaging service, often shaping all except the sermon (Scheer 2006:15). The music is marketed very effectively throughout the world. This has also had the unfortunate consequence that there is a 'use and discard' effect and an increasingly high turnover of music (Barnard 2006:55).

\section{Scheer (2006) writes perceptively:}

Though the Praise and Worship genre dominates the charts and churches today, some question how long this can last. Like any popular music, it will gain momentum, become overplayed, then be replaced by a new fad ... Any trend that so permeates the market will eventually become a caricature of itself rather than the refreshing expression it once was. My hope is that when the Praise and Worship style recedes, it will leave room for exciting and authentic local expressions of worship. (p. 213)

Now that we are well into the second decade of the century, one can begin to see such a shift towards songs with more content, more proclamation and a renewed focus on context. Notable here are especially the songs of Stuart Townend but also those of Keith and Kristyn Getty and others. Songs of Fellowship IV was published in 2007, and 73\% of its songs

19.An exception is the song Der Mond ist aufgegangen by Matthias Claudius which is critical of rationalism. In the translation of David Schubert:

Conceited, boasting loudly / of all we do so proudly, / we blindly seek our way. We poor frail mortals, sinning, / mere webs of air are spinning, / and further from the goal we stray $(891 \mathrm{v} 4)$. have more than one verse, compared to the $42 \%$ in Songs of Fellowship I. Also, the verses tend to be longer. Many of those in Songs of Fellowship I were a mere one or two lines. The count in both books included only the songs of the last 30 years before publication and excluded those songs where only a word or phrase changed in each verse. This style shift towards more content has been gradual. Songs of Fellowship II has a count of $52 \%$ and Songs of Fellowship III a count of $59 \%$ of songs with more than one verse. This style shift can only be welcomed but may lead to people lamenting a decrease in the level of emotional fervour as even emotive tunes lose their power after a few verses.

It is too early to say where it will lead, but looking back, one can be fairly certain that the songs of the next generation will be different from those of today. They will, however, probably bring their own theological and musical excesses.

\section{Tracing the balance in musical styles}

As can be seen in the historical overview, there have been marked shifts in the opinions around what musical styles are appropriate for worship and how emotive the songs for Sunday worship are allowed to be. This article is located in the discipline of practical theology, not music. However, no study of songs can do without a study of melody, least of all in this case where the issue is the question of the emotional value of songs. Much of the emotional value of songs is rooted in the melody and in the question of how a particular song relates to the currently popular music style. In the dissertation, an attempt is made to find a way to evaluate tunes which is accessible to people not trained in music. Most of these elements can be detected by any singer who is familiar with printed music and does not require special training in music theory. I am myself a lay person, trained through choirs and instrument tuition but not professionally trained in music theory.

Musical styles have shifted through the centuries, increasingly rapidly in the last century and decades. Of every style, only some musical pieces (or songs) survive through the style shift into the next generation. The rest are no longer performed or sung though they may be rediscovered by a later generation. ${ }^{20}$ Each style has distinctive ways to use rhythm and harmony and elements such as steps and leaps. These elements go in and out of favour. This can be traced very clearly if one studies consecutive contemporary song collections. In the dissertation, four such German songbooks are studied, books which were used in the Lutheran congregations in South Africa: Missionsharfe (MH, first published 1852), Jesu Name nie verklinget (JN 1959), Sein Ruhm unsere Freude (SR 1981) and Feiert Jesus (FJ 1995). I also studied two consecutive official

20.An example of this is the transition from late baroque to the early classical musical style. The sons of Johann Sebastian Bach were instrumental in this. To be original,
they had to change the style of their father, which was at the time going out of they had to change the style of their father, which was at the time going out of favour (Politoske 1992:186). They helped devise a simpler style which supplanted the complex baroque style. The works of Johann Sebastian Bach went out of favour and were almost forgotten until the style shifted again and one of the romantic era composers, Mendelssohn, rediscovered and popularised JS Bach again (Einstein 1947:75-76). 
denominational hymnals: the Evangelisches Kirchengesangbuch (EKG, first published 1950) and the Evangelisches Gesangbuch (EG 1994).

The following elements were studied in particular, as they are some of the ways of expressing emotion in tunes:

- slurs

- large intervals (many sixths and sevenths)

- complex rhythms: dotted notes and syncopation

- slow rhythms: repeated and long notes.

A count was made of how many songs in each collection have four or more of these elements present.

\section{Slurs}

A slur is a musical arch, binding together several notes. In string instruments, they would be played on the same bow. In songs, this means that they will be sung on the same syllable, for example: The Lord's my shepherd I'll not want (Tune CRIMOND 387). If slurs incorporate steps or leaps of a third, it gives a peaceful lilting effect. Slurs are not too difficult, except if there are many in rapid succession. ${ }^{21}$ Slurs of larger intervals or more than two notes are more difficult to sing and give a more emotive or dramatic effect. Slurs had a high point of popularity in the 19th century. In the edition of Missionsharfe studied, $51 \%$ of the tunes have more than four slurs. Many others have at least one. The count gradually decreases: JN 27\%, SR 12\% and FJ 9\%, which is even lower than the count in the official hymnals, EKG $17 \%$ and EG 18\%, showing that this element is hardly used in contemporary music.

\section{Large intervals}

A tune progresses from one note to the next in intervals. One note up or down is called a step, and an interval of more than one note is called a 'leap'. In general, the greater the leap and the more of them there are, the more interesting and emotive the tune. It also becomes more difficult to sing. In music theory, one speaks of 'conjunct' and 'disjunct' melodies. 'Disjunct' melodies move in large intervals. They are more demanding and tend to 'impart drama, intense emotion and energy' while 'conjunct' melodies are those that move in small steps and are generally easier to sing. They have a 'sweeter, more lyrical effect' (Politoske 1992:29).

Different intervals also have different kinds of effects. Many fourths make a tune sound militant and energetic whilst many sixths or sevenths give a tune a rousing, even sentimental feel. Particularly, the use of sixths or sevenths has gone in and out of favour in musical styles. In the Missionsharfe, these large intervals are used in $47 \%$ of songs. Whilst this percentage has gone down, it is still an element which is used in contemporary songs to give a tune emotive

21.The beautiful tune, St. Clement, has 10 slurs in 17 bars: 'The day $\sim$ thou ga $\sim$ ves Lord is ended' (549). This is not excessive, but it does become tiring after a few verses and requires a fair amount of voice control. value: JN 40\%, SR 30\% and FJ 35\%. Lutheran denominational hymnals are much more cautious in their tolerance of the 'emotive intervals': EKG has 36 songs (9\%), and the EG has $44(8 \%)$ songs that use leaps of a sixth or seventh. The EG is generally more tolerant of emotive songs, but it is clear that this particular element is viewed critically.

The difference is less pronounced in the use of large intervals in general. The count here is of four or more leaps of a fourth or more. Except for Sein Ruhm, the contemporary songbooks all rendered counts of between $60 \%$ and $70 \%$. Sein Ruhm is comparable with the hymnals with a count in the $40 \%$ range. All tunes thus use intervals to express emotion, but in the case of the official hymnals, these will be mainly 4ths, 5ths or octaves.

\section{Complex rhythms}

Complex rhythms add energy and liveliness to a tune. They get the body moving. Syncopation is an element where a stress is created on a normally off-beat note. This is characteristic of jazz and spirituals. Dotted rhythms started coming into fashion in the 19th century, (MH 25\%) but peaked in Germany during the first half of the 20th century with highly militant tunes (JN 36\%). The use declined gradually (SR 21\% and FJ $14 \%)$. Again it is a style less often used in the official hymnals: EKG $8 \%$ and EG 10\%. Incidences of syncopation are almost non-existent before the second half of the 20th century: $\mathrm{MH}$ $0 \%$, JN $0.7 \%$ and SR $29 \%$. In the newest songbook, this is a highly popular element, used four or more times in $53 \%$ of the songs. Many other songs have at least one or two off-beat stresses. It is very sparingly used in the hymnals: EKG $1 \%$ and EG $2 \%$.

\section{Slow rhythms}

After the highly energetic jazz rhythms, a gradual style shift began to take place towards slower, more soothing and peaceful tunes, which culminated in the Worship style. One of the early innovations of this style shift was using repeated notes. This element works well where there is good accompaniment, but is difficult to sustain where there is no accompaniment to add interest. ${ }^{22}$

This element is again going out of favour, but is still used in contemporary songs: $\mathrm{MH} 0 \%$, JN 2\%, SF $22 \%$ and FJ $18 \%$. It is seldom used in the hymnals: EKG $0.7 \%$ and EG $1 \%$.

With the style change described above, there was also a move to longer notes. Whilst in rhythmic or militant tunes, the only long notes are at the end of a phrase or even only at the end of the whole tune, songwriters now draw out the notes within the tune to a whole bar or longer. They give the emotive feeling of standing in awe or waiting to receive something. This has made this element very effective in worship songs led by strong lead singers. They are not easy for untrained

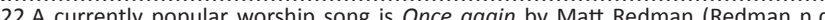
Online). Within four bars there are two sequences of 10 repeated A quavers whilst the guitar chord changes from $D$ to $G$ and back to $D$. This adds interest and gives an effect of reverent waiting. It does not work well without the instrumental backup. 
singers to sustain. This element is very prominent in the current worship song style: MH 0\%, JN 1\%, SR 14\% and FJ $28 \%$. In the hymnals, one finds the following: EKG $0 \%$ and EG $0.4 \%$.

\section{Issues arising out of style shifts}

It is very clear from the songbook comparisons that, in every contemporary collection, a particular style predominates, indicating how that generation generally expresses emotion in music. Those songs that fit the popular trend are effective, let people feel 'touched' and are probably effective evangelistic songs. However, as the style is so dominant, most songs sound similar in the end. Hymnals try to have a spread of themes and styles and thus only take the very best of each style and, generally, those songs that do not overuse the currently popular elements. When the style shifts and those elements go out of favour, most of the songs will disappear with it. It is only those songs which use the elements to special effect and are balanced in other ways which will survive the shift.

Official denominational hymnbooks bring stability but are often not on the pulse of what people in the pews really want to sing. Contemporary song collections bring together the best of their time, but still, much of it will not outlast their generation and has a very narrow range of themes. A good balance between the two will probably serve a congregation best.

\section{Tracing the balance in four songwriters}

In this section, I briefly look at how the cognitive and emotive balance is dealt with by two traditional and two contemporary songwriters, including a reference to three of their songs.

\section{Paul Gerhardt (1607-1676)}

In Lutheran hymnody, Paul Gerhardt is second in importance only to Luther himself, and his hymns are generally more popular and widely sung. He lived and worked in the years of strong Lutheran Orthodoxy where dogmatically correct content was all important. However, it was also the beginning of a rising new awakening of spirituality and personal faith experience in the pietistic movement. This dual influence means that Paul Gerhardt has a remarkably good balance between cognitive and emotive value in his songs. He lived during and after the devastating Thirty Years' War in Germany, and the pain and suffering associated with this deeply affected his writing, which centres on the cross and comfort in affliction.

Initially, he did not write for the Sunday service as there was a limited 'canon' of hymns for use in the service, which were mainly written by Luther and other Reformers (Albrecht 1995:40). He wrote mainly for use in home devotions and special family functions. This shows itself in his spread of themes which have many songs for church festivals and the daily and yearly cycle but relatively few for the church and the sacraments. All his hymns are content-loaded with many verses and a fair amount of teaching content. There is, however, much that touches the human emotions in the lyrics. The devotion and faith of the individual believer and the comfort one can take from the death and resurrection of Christ is strongly expressed in his hymns.

Paul Gerhardt did not write any tunes, but two church musicians in St. Nicolai, Berlin, first Johann Crüger and then Johann Georg Ebeling, set his texts to music, sometimes choosing existing tunes, sometimes writing their own. Both wrote tunes with emotive appeal. Those of Crüger are simpler and flowing or joyful. Those of Ebeling are generally more exuberant and dramatic. The good text-tune matches have much to do with the appeal of Gerhardt's hymns, particularly in their original German.

Three of his songs are studied detail in the dissertation. All have a good cognitive-emotive balance. The first hymn, $O$ sacred head, is based on a medieval original which is a poem of mystic devotion of the body of the crucified Lord. In Gerhard's translation, there is much biblical and theological content but also language which is worshipful and emotive. The tune by Hassler, PASSION CHORALE is lilting and reflective, emotive without being sentimental. Commit the ways you travel is comforting in its text, not highly emotive, but it does allow for the expression of experience. The tune, smooth and flowing in a minor key, is too heavy for some people, and they prefer a lighter tune from the 19th century, which does, however, fit less well with the serious content. The third hymn, The golden morning, with a tune by Ebeling, is the most emotive of the three. The tune is exuberant, with leaps and slurs. Also, the words have joyful exclamations and much assonance and alliteration which give them poetic power. However, there is teaching content in the song's encouragement to reflect on how fragile and precious life is, and it challenges people on how to live this life.

Paul Gerhardt's hymns have endured as they are both enjoyed for their musical value and treasured for their content. They are able to teach and comfort, express biblical truth and exuberant joy.

\section{Charles Wesley}

Charles Wesley's hymns were born out of the fervour of revival. He composed his first hymn 2 days after his conversion and never stopped writing hymns, producing over 6500 hymns in his lifetime.23 His hymns were indispensable to the Methodist movement, giving rise to the saying: 'Methodism was born in song. ${ }^{24}$ They were initially meant for open-air gatherings and not used in official services.

23. There is disagreement in scholarship as to how many hymns Charles wrote. Tyson writes: 'He wrote between six thousand and nine thousand hymns and sacred (a) poems (depending upon what one is willing to call a hymn or sacred poem), and more than four hundred of these continue in contemporary Christian hymnals' (Tyson 2007:viii)

24.This is the first sentence of the Preface to the Methodist Hymn Book (Stainer n.d.). 
The themes are wide and varied, but they centre on the conversion experience, the joy of faith and adoration of the glory of God. Many hymns are songs of praise and adoration (Wilson-Dickson 1997:186). Whilst the individual believer is central, there are many hymns written in the ' $\mathrm{We}^{\prime}$ form, expressing an awareness of the importance of community. ${ }^{25}$

Wesley has a good balance in his lyrics between the cognitive and the emotive. His verses are dense with theological content and scriptural allusions. They reveal his theological position which is evangelical: realistic about the depravity of the human condition but very optimistic about the possibility of change under the influence of God's spirit. His words are probably more emotive than those of Gerhardt. They express joy and awe, the fervour of revival and the passionate knowledge of our dependence on God's grace.

Wesley wrote lyrics only. His words have been matched to many different tunes, and this is a severe weakness of these hymns. Some tunes heighten the emotive value of the hymn whilst some undermine it. Of the three songs studied, one is matched to only one tune, Hark the herald angels sing to MENDELSSOHN (UMH 240). One hymn had two tunes: And can it be that I should gain. It is matched to SAGINA (UMH 363) and to ICH ARMER MENSCH (LH 67). This second tune is seldom sung and was probably chosen because the hymnal editors found SAGINA too emotive. However, it is a very uninspiring tune with straight crotchets all the way through, which does not match the fervour of the text at all. Other hymnals leave out the entire hymn. The third hymn, Love divine was matched to eight different tunes in the material studied for the dissertation. Of these, four tunes are discussed in more detail below.

It goes beyond the scope of this article to discuss in detail the issue of text-tune match in general and in these particular cases, but it is strongly argued that a good match of text and tune is indispensable to the appeal of a hymn or song and that tunes can strengthen or undermine texts. However it became clear in the research that this is not universally acknowledged.

Hark the herald angels sing is generally a fairly objective hymn. It explores the theological significance of the incarnation in a tightly knit web of scriptural references. The tune is emotive with many fourths and several repeated notes which come across as joyful shouts of joy. The text also has some exuberant exclamations which make it emotive. This hymn has a very good balance between cognition and emotion.

The hymn And can it be is less well represented in hymnals with some editors seemingly finding it too emotive. It is born out of a strong experience of conversion though it is put in general biblical imagery. This is something with which not all believers can identify. In general, both the text and the commonly used tune are more emotive than Hark the

25. Examples are Christ, from whom all blessings flow (UMH 550 ), And are we yet alive (UMH 553), All praise to our redeeming Lord (UMH 554), Blest be the dear uniting love (UMH 566) and others, all in the section 'United in Christ'. herald angels sing. The text has many exclamations such as 'For me!' and 'Amazing Love', amongst others, and some effective repetitions, for example the 'Tis mystery all! ... Tis mercy all!' in verses 2 and 3. This makes the text emotive. The tune SAGINA is dramatic with many leaps and slurs and relatively little repetition. It is not an easy tune to sing, but it provides a good match to the words, particularly the verse about the freedom from the prison. However, it is not a purely emotive song. There are much biblical content and proclamation, which has value in bringing across the basic Christian message. How this song will continue to be used and sung will have much to do with how well singers relate to the central message of overpowering awe at the experience of salvation.

The last hymn, Love divine, again has strong proclaiming content in its lyrics. The text is joyful and full of praise but strikes some more serious notes too, and there is emotive content in the text with phrases like 'pure, unbounded love', 'trembling heart', 'troubled breast' and 'lost in wonder, love and praise'. However, more emotion will come from the chosen tune. There were eight different tunes in the material encountered, of which only four are discussed. The success of the matches between tune and words varies widely.

There is much joy in the text which should be matched in the tune for the hymn to have maximum appeal. BLAENWERN (SF 377) is a very beautiful but fairly slow and meditative tune and should be matched to a more serious and meditative text. A suggestion would be to match it to the passion hymn I will sing the wondrous story, which is now usually sung to the more joyful HYFRYDOL (LBW 315). BEECHER (UMH 384) is a joyous even if slightly monotonous tune. It is well suited to the mood of the text but should perhaps be matched to a text which is sung less often, such as the Ascension hymn Alleluia sing to Jesus. The tune LOVE DIVINE (HAM 131) does not express much joy and could be sung to a more straightforward teaching text. HYFRYDOL is an emotive tune, lilting in places and fairly exuberant in others, especially the second to last line. It is the tune best matched to the mood of the text.

If one chooses a tune that is well matched to the text, the appeal of a hymn is greatly heightened. Most communities will sing the tune which they know, as this will have the emotive appeal of familiarity. However, if one were to introduce the hymn new to a community, one should choose the most fitting tune.

Wesley's hymns have been loved both for their emotive content and for their value in faith teaching. This will probably continue to be the case. Some consensus in texttune matches would, however, be valuable.

\section{Graham Kendrick}

Graham Kendrick is one of the most successful and wellknown contemporary songwriters. He has been called the 'father of modern worship music' (Kendrick n.d.). His songs 
are listed on charts throughout the world and have also been translated into many languages. ${ }^{26}$

In terms of theological 'balance', spread of themes and styles, Kendrick's record is impressive. He studied revival movements and realised that much of the biblical knowledge of new converts comes from songs, more particularly 'from the singing of "Psalms, hymns and spiritual songs"' (St. Michael's Singers 1996:4), and he compiled an overview of current worship music (St. Michael's Singers 1996):

I began to realise that the subject matter being covered by contemporary Praise and Worship songs was quite narrow ... certain emphases may well arise from the work of the Holy Spirit, and are vital, but a balanced worship 'diet' needs the 'meat and potatoes' of foundational truth. (p. 4)

Graham Kendrick thus quite deliberately set about trying to cover a broad range of themes in his writings. He covers the Christian year, psalms and paraphrases of biblical texts. It is of interest to him to make accessible the valuable elements of the Christian liturgical and hymnological tradition and so connect this generation with the witness of countless previous generations. He has written new tunes or new settings for several hymns, hoping to make the words accessible to a new generation. There are several songs for communion and confession, not often covered by contemporary songwriters (Kendrick n.d.).

Graham Kendrick uses a wide variety of musical styles in his songs. These songs were trendsetters in the 1980s. Now that the 'Praise and Worship style' has become fashionable, they sound more conventional. His style is his own and determined by the content rather than the music fashion.

His most successful song was Shine, Jesus, Shine (SF 362), which captured the spirit of the longing for revival that was wakening all over the world. It became the iconic song of the March for Jesus movement and is dated to 1987. It is Kendrick's most well-known song, sung all over the world, translated into many languages. It is consistently near the top of the CCLI charts and became one of the top ten hymns in the BBC's Songs of praise (St. Michael's Singers 1996:5). This song has a fair amount of biblical content though it is kept very simple and accessible. Songs of fellowship I lists six biblical references, and one may add others, such as Genesis 1 'Let there be light'. It is a song that is not purely emotive although it has strong emotive appeal. Some of this comes from the lyrics as in the exclamations, 'Shine, Jesus, shine,' 'Blaze, Spirit, blaze', 'Flow, river, flow', or in the prayerful 'Shine on $\mathrm{me}^{\prime}$. Most of the appeal in the tune comes from the chorus, which was added a long time after the verses were written. However, the contrast between slower, more reverent verse and exuberant and joyful chorus works very well. There is much repetition which makes the tune easy to learn, but it has enough variation in order not to get boring (though it did

26.For example, in the German songbook Ich will dir danken 1996. See below there are two Kendrick songs in translation: Shine Jesus, Shine (IWD 428) and Servan King (IWD 292). get sung too often when its popularity peaked). It is a wellbalanced song.

The second hymn, Meekness and Majesty (SF 390), had less immediate popular appeal. Its lyrics are much deeper and more thought provoking but still very accessible. Its theme is the incarnation of the eternal King. It is a song not for evangelistic outreach but for a committed congregation. It has many scriptural allusions and puts biblical truth in a poetically powerful new way, as in the line, 'Wisdom unsearchable,/God the invisible,/Love indestructible/ in frailty appears'. The most emotive part of the lyrics is probably the exclamations of the Chorus: 'O what a mystery,/meekness and majesty,/bow down and worship/ for this is your God,/this is your God'. The tune is slow and reverent with many long notes in the chorus. With very good accompaniment, this can be very moving and emotive. With less effective accompaniment, it can become tedious and difficult. In general, the strength of this song is in its text more than its tune, and although it has emotive appeal, it will probably not become a firm favourite with congregations. It is, nevertheless worthwhile to teach it to a congregation for the expressive text but will probably remain a song for special occasions.

The last hymn studied is My Lord, what love is this with the title Amazing love (SF 398). This is also a song that has strength in both text and tune, but in this case, the weighting is generally on the emotive tune rather than the text. The text is biblical and expressive but less dense with scriptural allusions than other Kendrick texts. The tune is very slow and worshipful. This was one of the songs that helped establish the slow and intimate worship style in the early years. There are many long notes, which are emotive if there is good accompaniment. Unaccompanied, they could be experienced as tedious. However, it was one of the most popular of Kendrick's songs, the only one of his to be included in the South African CD 50 greatest praise and worship songs (Maranatha Record Company 2006), and probably the most well-known in South Africa after Shine, Jesus, shine. It is still a reasonably balanced song, having both cognitive and emotive components but more heavily weighted on the emotive side.

When one looks at Kendrick's work overall, he has a good balance of more content-centred and more emotive songs. Of course, each song in itself cannot be equally well balanced, but there are only few songs of Kendrick that do not have at least some element of both poles.

\section{Noel Richards}

Noel Richards, who co-wrote many songs with his wife Tricia, is one of the contemporary songwriters who has been included in the New hymnmakers series (St. Michael's Singers 1997). Noel and Tricia Richards have been influential in the Praise and Worship movement from its early beginnings. They are fairly typical of the core of the movement in their style and choice of themes. Many of their songs have their 
focus on the act of worship. There is also biblical content though a lot less dense than in Kendrick's songs. Another aspect of Richards' writing is the strong focus on spiritual warfare. More than a handful of songs centre on the central Christian event, Christ's death and resurrection.

The first song chosen for analysis was You laid aside Your majesty (SF 633), a simple paraphrase of the Christ hymn in Philippians 2. There is a good balance between theological content and emotion. Whilst the content load is not high, the first part gives the essential 'facts' of the Christian story in ways which are stimulating and new, not excessively clichéd. Emotion is expressed especially in the chorus. Emotive words are used such as 'You have won my heart'. The song expresses love, adoration and amazement. It also has a fairly emotive tune.

The second song chosen was By your side (SF 55). In this song, there is little theological or biblical content to speak of. The language is taken from secular love poetry rather than from biblical examples. The song is purely an expression of adoration and emotion and contains many highly emotive, even erotic words: 'lover', 'in Your arms I would lay' and 'adore you'. The tune is also emotive. This is a 'one-sided' song but can still be used in intimate worship. It would be good to have more content-centred songs in the same service.

The last song is Filled with compassion (SF II 716), which demonstrates that the Richards couple is capable of more content-based songs. This song is a passionate call for the evangelisation of the world, something which is God's concern and passion too. There are several scriptural allusions and poetically strong language, showing God's concern for 'all the people of the earth'.

Much of the text is emotive, trying to generate passion for evangelism. There are many emotive words such as 'Your heart is breaking' or 'stir us to action filled with Your passion ...' The text also deals with the question about what will happen to the lost with highly emotive phrases such as 'dying without knowing you' or 'lost forever'. The vision of the end times is also emotive: the redeemed are 'Jesus' reward' and Jesus is satisfied with his life and sacrifice. However, there are elements of cognitive content, so there is some balance.

In general, the songs of Richards slightly broaden the range of themes usually covered in Praise and Worship songs, and although their theology is one-sided and sometimes triumphalist, the best of his work does deserve credit, and some will probably survive into the next generation though probably in slightly simplified oral versions.

\section{How to balance the cognitive and the emotive in songs}

To argue that there should be a balance between the cognitive and the emotive in songs is relatively simple. To maintain such a balance practically in Sunday worship is much more difficult and requires some sensitivity when working with worship teams. One needs to take into consideration what people enjoy singing and make sure that some of these songs are included, even though they may have relatively low theological value. In the Lutheran service structure, such songs can be included in the introductory section or at the end. More content-centred songs are then included in the word section of the service. However, one needs to evaluate the songs with popular appeal and particularly distinguish between songs which have little or one-sided theological content and those which actually have problematic theology in their texts.

What is judged to be wrong theology is obviously dependent on one's theological position. Lutheran theology would guard against songs that pressurise people into conversion through threats of hell or are too legalistic or emphasise someone's own achievement in having attained faith. ${ }^{27}$ Theologically problematic are also songs which emphasise success and promise a freedom from problems if we follow Jesus. The most theologically problematic line found in the course of this research is the line, 'In his presence all our problems disappear'.$^{28}$ One should try to avoid such songs if possible. Sometimes, songbook editors rewrite lines. This is possible where a song is no longer in copyright. Changing lines of songs where the songwriter is still alive is a very different and problematic issue. It does happen, such as in the song mentioned above which, in an unpublished song-collection, is changed to, 'In his presence our purpose becomes clear'. However here it is safer to leave out the song completely.

Most songs are not so much theologically wrong as one-sided. This means that they can be used as long as other songs which can restore the balance are also sung. For example, there are many songs which emphasise only the divinity and the glory and power of Christ without mentioning his humanity and his suffering for us. Many songs are excessively subjective and emphasise only our action of worship or response in faith, without acknowledging the act of God. Many of these songs can be used in worship to great effect, but one always needs to acknowledge that what people sing will ultimately affect their theology. One needs to weigh up the positive 'enjoyment' value against the detrimental effect it may have on the theology of the singers. Kennel (2011:32) argues that good songs allow people to be drawn in whilst determining themselves their closeness and distance, enabling dialogue without manipulation.

Emotive appeal, of course, also has to do with familiarity. Once people get to know even not so emotive songs, their appeal is heightened, particularly when one begins to have

\footnotetext{
27.The not so subtle pressure of the song Beinah bekehret! ('Almost converted') would probably exclude the song from a mainstream Lutheran hymnal (JN 54).

28.'His Spirit in us releases us from fear,

The way to Him is open, with boldness we draw near.

And in His presence our problems disappear;
Our hearts responding to His love. (Maranatha Record Company 2006)
} 
positive memories associated with them or when their power to comfort and strengthen faith becomes apparent. Such songs become 'friends' and begin to accompany people through life and be sung outside public worship.

The comparison of a song to a friend was made by the German poet and hymn writer Matthias Claudius. A song is like a 'good friend in your house' (quoted in Lieberknecht 1994:60), whose qualities and function is difficult to exactly define and describe but whose strengths and weaknesses one knows and with whom one has a shared history. The process of a song becoming a 'friend' is similar to the process of 'fusion of horizons' described by Gadamer (see previous section). The singer enters in some way into the faith experience of the writer and uses the writer's words to express his or her personal faith experience. This is a powerful emotive process.

Choosing carefully which songs to teach a congregation and repeating them often to increase familiarity can turn theologically valuable songs into songs with deep emotional value for congregants. Undoubtedly though, this can only be successful if the tune is reasonably singable.

\section{Conclusion}

Leading worship and choosing songs both for their emotive and proclamation value will remain a challenge. There are many songs which have a good balance of both, and they should be found and given a home in the congregation. This should be done sensitively so that people do not feel they are being deprived of their favourites. However, my experience in the course of my research in informal discussions with worship leaders and students has been that people generally react positively to the idea of balance and understand its importance. One does not need to take away people's favourite songs, unless they are clearly theologically wrong. Rather, one can add a richness of valuable old and new songs which have the potential to become favourites as well.

Singing remains a behaviour that goes to the heart of Christian identity and ministry. It is worth finding ways to help so that it will be most effective, comforting and enriching.

\section{Acknowledgements Competing interests}

The authors declare that they have no financial or personal relationship(s) that may have inappropriately influenced them in writing this article.

\section{Authors' contributions}

J.G.T. (University of Pretoria) wrote this article as part of the requirements of her $\mathrm{PhD}$ with the University of Pretoria. C.J.W. (University of Pretoria) and C.V. (University of Pretoria) were the supervisors and gave suggestions and critical feedback.

\section{References}

\section{Hymnals and Song Books}

EG Evangelisch-Lutherische Kirche in Niedersachsen und Bremische Evangelische Kirche, 1994, Evangelisches Gesangbuch, Lutherisches Verlagshaus, Hannover.

EKG Evangelisch-Lutherische Kirche Niedersachens, 1974, Evangelisches Kirchengesangbuch, Schlütersche Verlagsanstalt, Hannover.

FJ Becker, H. (ed.), 1995, Feiert Jesus - Das Jugendliederbuch, Hänssler Verlag, Holzgerlingen.

HAM Council of H.A.M., 1983, Hymns ancient and modern:Melody edition, Canterbury Press, Norwich.

IwD Heizmann, K., 1996, Ich will dir danken:Lieder für die Gemeinde, Hänssler Verlag, Neuhausen, Stuttgart.

JN Riecker, O., 1976, Jesu Name nie verklinget, Friedrich Hänssler, NeuhausenStuttgart.

LBW Inter-Lutheran Commission on Worship, 1978, Lutheran book of worship (LCW), Augsburg Publishing House, Minneapolis.

Lutheran Church of Australia, 1995, Lutheran hymnal with supplement, Openbook Publishers, Aidelaide.

MH Bertelsmann, D., 1919, Kleine Missionsharfe im Kirchen- und Volkston, 79 Auflage, Bertelsmann, Gütersloh.

MP Horrobin, P. \& Leavers, G., 1990, Mission praise:Combined music edition, Marshall Pickering, London.

SF II Kingsway, 1998, Songs of fellowship: Music edition, vol. 2, Kingsway Music, Eastbourne.

SF III Kingsway, 2004, Songs of fellowship: Music edition, vol. 3, Kingsway Music, Eastbourne.

SF IV Kingsway, 2007, Songs of fellowship: Music edition, vol. 4, Kingsway Music, Eastbourne.

SR Cochlovius, J., 1981, Sein Ruhm unsere Freude, Cochlovius, Krelingen.

UMH United Methodist Church, 1989, United Methodist Hymnal, United Methodist Publishing House, Nashville.

\section{Audio resources and websites}

Kendrick, G., n.d., Official Website, viewed 20 February 2012 and 07 July 2013, from http://www.grahamkendrick.co.uk

Lutheran World Federation, 1996, 'Nairobi statement on worship and culture: Contemporary challenges and opportunities', viewed 20 July 2013, from http:// www.worship.ca/docs/lwf_ns.html

Maranatha Record Company, 2006, 50 greatest praise and worship songs, audio CD, Maranatha, Menlyn.

St. Michael's Singers, Coventry, 1996, The New Hymn Makers - Graham Kendrick Meekness and Majesty, CD and booklet, East Sussex, Kingsway Music.

St. Michael's Singers, Coventry, 1997, The New Hymnmakers - Noel and Tricia Richards, Chris Bowater, CD and booklet, East Sussex, Kingsway Music.

Stainer, J., n.d., 'Preface to the Methodist Hymn Book', viewed 11 March 2012, from http://www.stainer.co.uk/hymnquest/bs04.html

\section{Books and articles}

Albrecht, C., 1995, Einführung in die Hymnologie, Vandenhoek \& Ruprecht, Göttingen. Barnard, M., 2006, Liturgie voorbij de Liturgische Beweging, Meinema, Zoetermeer.

Blume, F., 1965, Geschichte der Evangelischen Kirchenmusik, Bärenreiter-Verlag, Kassel.

Bosch, D.J., 1991, Transforming mission: Paradigm shifts in theology of mission, Orbis Books, Maryknoll, NY.

Calvin, J., [1536] 1960, Institutes of the Christian religion, J.T. McNeill (ed.), The Westminster Press, Philadelphia.

Dawn, M., 1995, Reaching out without dumbing down: A theology of worship for the turn-of-the-century culture, William Eerdmans, Grand Rapids.

Deichgräber, R., 2002, Der Tag ist nicht mehr fern: Betrachtungen zu Liedern von Jochen Klepper, Vandenhoeck \& Ruprecht, Göttingen.

Eissfeldt, O., 1974, The Old Testament: An introduction, Basil Blackwell, Oxford.

Friedenthal, R., 1982, Luther: Sein Leben und seine Zeit, R. Piper \& Co Verlag, München.

Gadamer, H-G., 1975, Wahrheit und methode, JCB Mohr, Tübingen.

Green, J.P., 1985, The interlinear Bible, Hendrickson Publishers, Peabody.

Greinacher, N., 1974, 'Das Theorie-Praxis Problem in der Praktischen Theologie', in F. Klostermann \& R. Zerfass (eds.), Praktische Theologie Heute, pp. 103-118, Kaiser/Grünewald Verlag, München.

Heitink, G., 1993, Practical theology: History, theory, action domains, William B. Eerdmans, Grand Rapids.

Heyns, L.M. \& Pieterse, H.J.C., 1990, A primer in practical theology, Gnosis, Pretoria. 
Jeremias, J., 2004, 'Worship and theology in the Psalms', in D. Human \& C. Vos (eds.) Psalms and liturgy, pp. 89-101, T \& Clark International, London.

Kendrick, G., n.d., 'Official website', viewed 20 February 2012, from http:// www. grahamkendrick.co.uk

Kennel, G., 2011, 'Was ist gute Kirchenmusik?: Chancen und Grenzen de Qualitätsdebatte für ein zentrales kirchliches Arbeitsfeld', Zeitschrift der Liturgischen Konferenz für Gottesdienst, Musik und Kunst 3, 24-36.

Leith, J.H., 1981, An introduction to the reformed tradition, John Knox Press, Atlanta.

Letsosa, R.S. \& De Klerk, B.J., 2007, 'A relevant liturgy for reformed churches of African origin concerning liturgical music', Practical Theology in South Africa 22(1), 64-82.

Leupold, U.S., 1965, 'Introduction to volume 53', in U.S. Leupold (ed.), Luther's works, vol. 53, pp. xiii-xx, Fortress Press, Philadelphia.

Lieberknecht, U., 1994, Gemeindelieder: Probleme und Chancen einer kirchlichen Lebensäußerung, Vandenhoek \& Ruprecht, Göttingen.

Long, T.G., 2001, Beyond the worship wars: Building vital and faithful worship, The Alban Institute, Durham.

Luther, M., [1524] 1965, 'Preface to the Wittenberg Hymnal', in U.S. Leupold (ed.), Luther's works, vol. 53, pp. 315-316, Fortress Press, Philadelphia.

Luther, M., [1538] 1965, 'A preface for all good hymnals', in U.S. Leupold (ed.), Luther's works, vol. 53, pp. 319-320, Fortress Press, Philadelphia.

Luther, M., [1543] 2007, 'Von den letzten Worten Davids', in K. Drescher (ed.), Martin Luthers Werke, Weimarer Ausgabe (WA), vol. 54, pp. 28-100, Hermann Böhlaus, Weimar.

Luther, M., [1545] 1965, 'Preface to the Bapst Hymnal 1545', in U.S. Leupold (ed.) Luther's works, vol. 53, pp. 332-334, Fortress Press, Philadelphia.

Luther, M., 1854, 'Tischreden Doct. Martin Luthers von der Musica', in J.K. Irmischer (ed.), Dr. Martin Luther's sämmtliche Werke, Erlanger Ausgabe (EA), vol. 62, pp. 307-311, Heyder \& Zimmer Verlag, Frankfurt.

Luther, M., 1854, 'Tischreden Doct. Martin Luthers von Schulen und Universitäten', in J.K. Irmischer (ed.), Dr. Martin Luther's sämmtliche Werke, Erlanger Ausgabe (EA), vol. 62, pp. 285-307, Heyder \& Zimmer Verlag, Frankfurt \& Erlangen.

Morgenthaler, S., 1995, Worship evangelism: Inviting unbelievers into the presence of God, Zondervan Publishing House, Grand Rapids.

Müller, A., 1974, 'Praktische Theologie zwischen Kirche und Gesellschaft', in F. Klostermann \& R. Zerfass (eds.), Praktische Theologie Heute, pp. 15-26, Kaiser/ Grünewald Verlag, München.
Nüchtern, M., 2008, “'Holder Knabe im lockigen Haar"- oder:Ein bisschen Kitsch darf sein', Arbeitsstelle Gottesdienst: Zeitschrift der Gemeinsamen Arbeitsstelle für Gottesdienstliche Fragen 22(3), 5-15.

Osmer, R., 2008, Practical theology: An introduction, William Eerdmans, Grand Rapids. Politoske, D.T., 1992, Music, Prentice Hall, Englewood Cliffs.

Redman, R., 2002, The great worship awakening: Singing a new song in the postmodern church, Jossey-Bass, San Francisco.

Reinke, S.A., 2011, 'Plädoyer für eine (zeitgemäße) Kirchenmusikästhetik im 21. Jahrhundert', Liturgie und Kultur: Zeitschrift der Liturgischen Konferenz für Gottesdienst, Musik und Kunst 2(3), 5-23.

Routley, E., 1983, Christian hymns observed, Alden Press, Oxford.

Scheer, G., 2006, The art of worship: A musician's guide to leading modern worship, Baker Books, Grand Rapids.

Söhngen, O., 1967, Theologie der Musik, Johannes Stauda Verlag, Kassel.

St. Michael's Singers, Coventry, 1996, The new hymn makers: Graham Kendrick Meekness and Majesty, CD and booklet, Kingsway Music, East Sussex.

St. Michael's Singers, Coventry, 1997, The new hymnmakers: Noel and Tricia Richards, Chris Bowater, CD and booklet, Kingsway Music, East Sussex.

Taylor, C., 2002, 'Understanding the other: A Gadamerian view of conceptual themes', in J. Malpas, U. Answald \& J. Kertscher (eds.), Gadamer's century: Essays in honour of Hans-Georg Gadamer, pp. 279-298, MIT Press, Cambridge.

Thompson, B., 1961, Liturgies of the Western church, Fortress, Philadelphia.

Tyson, J.R., 2007, Assist me to proclaim: The life and hymns of Charles Wesley, Eerdmans, Grand Rapids.

Van de Laar, J.W., 2000, A theological exploration of the role and use of music for worship in the Methodist Church of Southern Africa, UNISA, Pretoria.

Van der Ven, J., 1993, Practical theology:An empirical approach, Kok Pharos, Kampen.

Wainwright, G. \& Tucker, K., 2006, The Oxford history of Christian worship, Oxford University Press, Oxford.

Webber, R., 1994, Worship old and new, Zondervan, Grand Rapids. Wilson-Dickson, A., 1997, A brief history of Christian music, Lion, Oxford.

Zenger, E., 1997, Die Nacht wird leuchten wie der Tag: Psalmenauslegungen, Herder, Breisgau. 